\title{
ANALISIS PENGGUNAAN STRATEGI STRATTA DALAM PEMBELAJARAN MENULIS PUISI SISWA KELAS XI SMA NEGERI 1 SUNGGUMINASA
}

\author{
Dr. H. Muh. Amin, M. Pd. \\ SMA Negeri 1 Sungguminasa Kabupaten Gowa, NIP. 195811081984111002 \\ aminnyampa58@yahoo.com
}

\begin{abstract}
ABSTRAK
Penelitian ini bertujuan untuk menjawab kemampuan menulis puisi siswa kelas XI SMA Negeri 1 Sungguminasa melalui penerapan strategi Stratta? dan Apakah strategi Stratta efektif diterapkan dalam meningkatkan kemampuan menulis puisi siswa kelas XI SMA Negeri 1 Sungguminasa?" Jenis penelitian ini adalah penelitian eksperimen yakni melakukan penelitian secara mendalam dan menguji hipotesis. Populasi penelitian ini adalah keseluruhan siswa kelas XI SMA Negeri 1 Sungguminasa yang berjumlah 101 orang yang terbagi atas empat kelas, sedangkan sampel penelitian ditetapkan kelas XI sebanyak 25 orang sebagai kelas eksperimen dan kelas $\mathrm{X} 2$ sebanyak 25 orang sebagai kelas kontrol. Teknik pengumpulan data yang digunakan dilakukan dengan teknik observasi dan memberikan tes menulis puisi. Data yang terkumpul dalam penelitian dianalisis dengan menggunakan teknik statistik inferensial. Berdasarkan hasil analisis data, terlihat bahwa nilai keefektifan strategi Stratta dalam meningkatkan kemampuan menulis puisi siswa kelas XI SMA Negeri 1 Sungguminasa sebesar 2,43. Berdasarkan nilai $\mathrm{t}$ hitung tersebut dapat dibandingkan dengan nilai $\mathrm{t}$ tabel $\mathrm{db}=\mathrm{N}-1=25-1=24$. Jadi, $\mathrm{db} 25-1=$ 24 dan $\mathrm{t}=0,5$ (tabel terlampir). Sementara, $\mathrm{t}_{\text {hitung }}=2,43$ dan $\mathrm{t}$ tabel $=2,064$ (signifikan 5\%). Dengan demikian, $\mathrm{t}$ hitung $>t$ tabel. Perbandingan hasil kemampuan pretes dan postes menunjukkan bahwa nilai $t_{\text {hitung }}$ sebanyak 2,43> nilai $\mathrm{t}$ tabel 2,064. Hal ini menunjukkan bahwa hipotesis penelitian yang diajukan diterima. Diharapkan Guru hendaknya menggunakan strategi strata dalam pembelajaran, karena strategi ini efektif diterapkan dalam meningkatkan kemampuan mengapresiasi puisi siswa kelas XI SMA Negeri 1 Sungguminasa.

Kata Kunci: Strategi, stratta, menulis puisi, dan siswa
\end{abstract}

\begin{abstract}
This study aimed to answer the ability to write poetry class XI student of SMAN 1 Sungguminasa through the implementation of strategies Stratta? and Is Stratta effective strategy implemented to improve the ability to write poetry class XI student of SMAN 1 Sungguminasa? "This type of research is an experimental research which is doing in-depth research and testing hypotheses. The study population was the whole class XI student of SMAN 1 Sungguminasa totaling 101 people, divided into four classes, while the eleventh grade study sample set of 25 people as an experimental class and class X2 as many as 25 people as a control group. Data collection techniques used is done by observation and provide a test write poetry. Data collected in the study were analyzed using inferential statistical techniques. Based on the analysis, it appears that the effectiveness of the strategies Stratta in enhancing the ability to write poetry class XI student of SMAN 1 Sungguminasa of 2.43. Based on the $t$ value can be compared with the value $t$ ta $\neg$ bel $d b=N-1=25-1=24$. So, $d b 25-1=24$ and $t=0.5$ (table attached). Meanwhile, $t=2.43$ and $t_{\text {table }}=2.064$ (5\% significance). Thus, $t>t_{\text {table }}$. Comparison of the ability of pretest and posttest results showed that the total value of $2.43 t_{\text {count }}>t_{\text {table }} 2.064$. This shows that the hypothesis proposed accepted. Teachers should be expected to use learning strategies in strata, because this strategy effectively applied in improving the ability to appreciate poetry class XI student of SMAN 1 Sungguminasa.
\end{abstract}

Keywords: Strategy, stratta, writing poetry, and students

\section{PENDAHULUAN}

Kompetensi dasar menulis kreatif (menulis puisi) itu mempunyai dua tujuan utama. Pertama, siswa menggunakan bahasa untuk memahami, mengembangkan, dan mengomunikasikan gagasan dan informasi, serta untuk berintegrasi dengan orang lain. Kedua, para siswa juga diharapkan dapat memahami dan berpartisipasi dalam kegiatan menulis kreatif agar mereka dapat menghargai karya artistik, budaya, intelektual, serta menerapkan nilai-nilai luhur untuk meningkatkan kematangan pribadi menuju masyarakat beradab (Depdiknas, 2007: 15).

Pembelajaran menulis puisi dapat membantu siswa untuk mengekspresikan gagasan, perasaan, dan pengalamannya. Dengan melatih siswa menulis puisi, seorang guru dapat membantu siswa mencurahkan isi hatinya, ide, dan pengalamannya melalui bahasa yang indah. Dengan menulis puisi, 
dapat mendorong siswa untuk belajar bermain dengan kata-kata, menafsirkan dunianya dengan suatu cara baru yang khas, dan menyadari bahwa imajinasinya dapat menjadi konkret bila ia dapat memilih katakata dengan cermat untuk ditulis dalam puisi.

Menulis puisi tidak hanya bertujuan untuk mempertajam dan meningkatkan kemampuan bahasa, tetapi juga diharapkan dapat memperoleh minat segar yang muncul dari kedalaman puisi itu sendiri. Menyadari pentingnya pembelajaran menulis puisi bagi siswa di SMA, maka pembelajaran tersebut perlu mendapat perhatian yang besar. Akan tetapi, kenyataan di lapangan menunjukkan bahwa pembelajaran menulis puisi di sekolah masih mengalami kendala dan cenderung dihindari oleh sebagian siswa. Hal ini disebabkan metode yang digunakan guru dalam peembelajaran puisi masih kurang sehingga siswa kurang berminat dalam pembelajaran puisi ini.

Sebenarnya, siswa dapat menulis puisi dengan mencurahkan ide, bentukbentuk puitis, rima, dan aturan-aturan dalam menulis puisi. Akan tetapi, pada

kenyataannya siswa belum mampu melaksanakan kegiatan menulis puisi secara optimal. Hal ini diduga disebabkan oleh kegiatan pembelajaran yang kurang menarik. Kendala yang terkadang ditemui oleh siswa dalam menulis puisi antara lain, siswa kesulitan menemukan ide, kesulitan menentukan kata-kata pertama dalam menulis puisi, kesulitan mengembangkan ide menjadi puisi karena minimnya penguasaan kosakata, dan kesulitan menulis puisi karena tidak terbiasa mengemukakan perasaan, pemikiran, imajinasinya dalam menulis puisi.

Berdasarkan hasil observasi SMA

Negeri 1 Sungguminasa masih banyak siswa yang tidak memenuhi standar KKM.

Standar kompotensi pelajaran Bahasa dan Sastra Indonesia untuk SMA/MA yaitu:

1. Mampu mendata objek yang akan dijadiakan bahan menulis puisi;

2. Mampu menulis puisi dengan menggunakan pilahan kata yang tepat: dan

3. Mampu menyunting puisi sendiri"

Melihat kenyataan pembelajaran menulis puisi yang belum memenuhi harapan, perlu ditempuh upaya untuk mengefektifkan kegiatan pembelajaran menulis puisi di kelas. Dalam hal ini, diperlukan suatu teknik yang dapat membantu siswa mengatasi permasalahan dalam menulis puisi. Salah teknik yang tepat untuk memudahkan siswa dalam mencipta sebuah karya sastra. Dalam hal mencipta puisi, yaitu melalui penerapan strategi stratta. Strategi stratta diharapkan dapat meningkatkan pembelajaran menulis puisi pada tingkat SMA. Melalui teknik tersebut, siswa merasa diharapkan mampu menulis puisi berdasarkan unsur-unsur batin puisi lain yang telah dikaji.

Berdasarkan fenomena tersebut, maka pembelajaran menulis puisi mengharuskan guru untuk menerapkan teknik yang tepat dan sesuai agar kemampuan menulis puisi dapat meningkat. Teknik yang diterapkan ini mampu membimbing dan mengarahkan siswa untuk mengatasi kendala-kendala yang dihadapinya dalam menulis puisi. Siswa terlebih dahulu mempelajari puisi lain sebagai modal utama dalam mempermudah menulis puisi.

\section{TELAAH PUSTAKA}

\section{a. Pembelajaran Sastra}

Tujuan pembelajaran sastra bagi siswa di sekolah menengah umum diharapkan mampu menikmati, memahami, dan memanfaatkan karya sastra untuk mengembangkan kepribadian, menciptakan nilai estetika dalam berbahasa, menambah wawasan tentang kehidupan, serta meningkatkan dan memperluas kemampuan berbahasa.

Begitu pentingnya sastra dalam pembinaan kehidupan manusia, Ambo Enre, dkk. (Sutjarso, 2006: 5) mengemukakan tiga kedudukan penting sastra dalam membina kehidupan manusia. Pertama, sastra suci yang di dalamnya diceritakan tentang kehidupan cikal-bakal mereka yang sakti dan dimuliakan. Pendidik harus berusaha mengarahkan anak didik menangkap nilainilai yang bersemayam di dalam tokoh cerita itu. Kedua, sastra berguna karena di dalamnya terdapat petunjuk tentang hal yang boleh dan yang tidak boleh dilakukan guna menjaga integritas dan stabilitas sosial serta kelestarian pranata dan budaya. Ketiga, sastra indah yang di dalamnya terdapat cerita 
petualangan, percintaan, dan peperangan yang memikat dan menegangkan dengan gaya bahasa yang berpretensi estetis.

Kegiatan menulis itu adalah suatu proses, yaitu proses penulisan yang melewati beberapa tahap, yakni pramenulis, tahap penulisan, dan tahap revisi. Ketiga tahap penulisan menunjukkan kegiatan utama yang berbeda. Dalam tahap pramenulis akan ditentukan hal-hal pokok yang akan ditulis, tahap penulisan akan dilakukan kegiatan mengembangkan gagasan dalam kalimat, paragraf, dan wacana (Ackhadiat, 1994: 2).

Pada waktu proses menulis berlangsung, setiap orang akan melewati tahapan-tahapan menulis yang sama, yaitu pramenulis, tahap pemburaman/pengedrafan, dan tahap perevisian untuk memperbaiki tulisan yang sudah dihasilkan. Pada dasarnya ada lima tahap proses kreatif menulis, yaitu: (1) tahap persiapan, pada tahap ini penulis menyadari apa yang akan dia tulis, (2) tahap inkubasi, pada tahap ini gagasan yang telah muncul tadi direnungkan kembali oleh penulis, (3) tahap inspirasi, pada tahap ini penulis menyadari gagasan apa yang akan dia tulis, (4) tahap penulisan, pada tahap ini penulis mengungkapkan apa yang akan dia tulis, dan (5) tahap revisi.

Uraian dan penjelasan tentang proses menulis yang telah dikemukakan di atas pada hakikatnya sama. Proses menulis merupakan kegiatan mengungkapkan ide atau gagasan, pikiran, perasaan, dan pengalaman dengan melalui tahapantahapan menulis. Seseorang yang melakukan kegiatan menulis disadari atau tidak akan selalu melalui suatu tahapan-tahapan dalam proses yang dilakukan. Tahapan-tahapan dalam proses menulis tersebut secara umum meliputi kegiatan pramenulis, penulisan, dan revisi hasil tulisan. Tahap-tahap yang dilewati seorang penulis pada waktu menuangkan gagasannya akan menjadi panduan untuk menghasilkan suatu tulisan yang sesuai dengan apa yang direncanakan(Ackhadiat, 1994: 2).

Sebagai puncak kemampuan berbahasa, kegiatan menulis menuntut kemampuan yang kompleks. Bukan hanya membutuhkan pensil, kertas, mesin ketik atau komputer melainkan yang lebih penting adalah kemampuan memilih atau menentukan ide atau topik tulisan, menemukan fakta, mengorganisasi materi yang akan ditulis, menyatukannya sampai menjadi suatu tulisan dan sebagainya.

Menulis kreatif merupakan kegiatan menulis yang berkembang dari gagasan yang kreatif. Mirriam (2006: 169) menyatakan bahwa menulis kreatif merupakan gagasan yang mengalir dari pikiran seseorang ke dalam sebuah tulisan. Gagasan kreatif yang sudah diungkapkan dalam bentuk tulisan akan menggambarkan hal-hal yang ingin dikemukakan oleh penulis.

Menulis kreatif merupakan proses penciptaan karya sastra. Proses itu dimulai munculnya ide dalam benak penulis, menangkap dan merenungkan ide (biasanya dengan cara dicatat), mematangkan ide agar jelas dan utuh, membahasakan ide tersebut dan menatanya (ini masih dalam benak penulis), dan menuliskan ide tersebut dalam bentuk karya sastra. Oleh karena itu, tulisan kreatif sastra tidak hanya bersifat mekanistis saja. Dalam menulis kreatif sastra seseorang harus mampu menghubungkan dan memanfaatkan schemata yang dimilikinya, sehingga tulisan yang dilahirkan baik dan menarik untuk dibaca (Roekhan, 1991: 20).

\section{b. Puisi}

Puisi adalah salah satu bentuk kesusastraan yang tertua usianya. Puisi adalah pengkonsentrasian. Puisi ini mengkonsentrasikan pada dirinya segala kesan perasaan dan pikiran dengan pengucapan yang padat (Nensilianti, 2006: 23). Puisi adalah sebuah karya sastra seni yang tersusun dari bermacam-macam unsur dan sarana kepuitisan; puisi itu karya estetis dan bermakna, yang mempunyai arti, bukan hanya sesuatu yang kosong tanpa makna (Pradopo, 2002: 3).

Beberapa ahli telah memberikan batasan tentang puisi. Slamet Mulyana (Waluyo, 1995: 23) mengatakan bahwa puisi merupakan bentuk kesusastraan yang menggunakan pengulangan kata sebagai cirri khasnya, pengulangan kata itu menghasilkan rima, ritme, dan musikalitas. James Reeves (Waluyo, 1995: 23) memberikan batasan yang berkaitan dengan struktur fisik dengan menyatakan bahwa puisi adalah ekspresi bahasa yang kaya dan penuh daya pikat.

Selanjutnya, Altemberd (Pradopo, 2002: 5) mengungkapkan puisi adalah as the interpretive dramatization of ekspensience 
in metrical language pendramaan pengalaman yang bersifat penafsiran dalam bahasa yang berirama (bermetrum). Samuel Taylor Coleridge (Pradopo, 2002: 6) mengemukakan bahwa puisi itu adalah katakata terindah dalam susunan terindah Wordswoth (Pradopo, 2002: 6) mengungkapkan bahwa puisi adalah pernyataan perasaan yang imajinatif, yaitu perasaan yang direkakan atau diangankan.

\section{c. Strategi Stratta}

Strategi ini berasal dari tulisan Leslei Stratta dalam bukunya Pattems of Language sehingga dinamakan strategi Stratta. Menurut strategi ini, dalam mengajarkan sastra ada tiga tahap yang harus dilakukan yaitu tahap penjelajahan, tahap interpretasi, dan tahap re-kreasi.

Tahap penjelajahan adalah tahap memahami atau menghayati karya sastra. Penjelajahan dapat dilakukan dengan membaca, bertanya, mengamati, dan kegiatan lain yang bertujuan untuk mendapatkan pemahaman tentang karya sastra yang sedang dijelajahi.

Tahap interpretasi adalah tahap penafsiran terhadap karya sastra yang telah dijelajahi. Penafsiran dapat dilakukan pada unsur-unsur yang membentuk sebuah karya sastra. Dapat pula dikaitkan dengan peristiwa-peristiwa yang pernah dialami.

Tahap re-kreasi adalah tahap pendalaman. Mengkreasikan kembali atau penciptaan kembali karya sastra baru sesuai dengan pemahaman dan penafsiran dari karya sastra yang telah dibaca sebelumnya.

Seperti yang telah dijelaskan sebelumnya bahwa strategi stratta memiliki tiga tahap yaitu, tahap penjelajahan, tahap interpretasi dan tahap re-kreasi. Pada bagian ini akan dijelaskan penerapannya dalam pembelajaran menulis puisi. Kegiatan pada tahap penjelajahan adalah memberikan kesempatan kepada setiap siswa untuk menikmati karya sastra dengan cara mereka sendiri. Pada tahap ini, tugas siswa adalah membaca puisi dan mencatat kesan-kesan yang diperolehnya dari kegiatan membaca, serta mencatat berbagai unsur-unsur yang terdapat di dalam puisi yang telah ditentukan. Kemudian siswa membentuk atau menentukan konsep berdasarkan datadata atau kesan-kesan yang diperoleh dari puisi yang telah dibaca. Ini sejalan dengan tahapan dalam proses menulis secara umum, dimana ada tahap pramenulis atau tahap persiapan yaitu memilah-milah hal-hal pokok yang akan ditulis(Rahmanto, 1988:47)

Pada tahap interpretasi, kegiatan yang dilakukan oleh siswa adalah memberikan penafsiran atau pemahaman terhadap puisi yang dibaca, menganalisis unsur-unsur dalam puisi, dan mendiskusikan puisi yang telah mereka baca serta memberikan kesimpulan serta dapat pula mengaitkannya dengan pengalaman yang pernah dialami oleh siswa. Dari hasil analisis, siswa merenungkan kembali ide-ide pokok yang sering disebut inkubasi dalam proses menulis. Kemudian memantapkan gagasan yang telah direnungkan tersebut dengan inspirasi-inspirasi yang baru dari penulis.

Pada tahap re-kreasi, langkah ini adalah langkah pendalaman. Pada tahap inilah siswa mewujudkan semua yang telah mereka lakukan pada tahap sebelumnya dalam bentuk tulisan. Siswa diminta mengkreasikan kembali apa yang telah dipahaminya dari hasil tahap penjelajahan dan tahap interpretasi terhadap karya sastra. Re-kreasi dapat diartikan pula sebagai upaya penciptaan kembali dengan tidak lepas dari konsep-konsep sebelumnya yang telah direnungkan baik-baik dan dikreasikan dengan inspirasi-inspirasi baru dari penulis. Re-kreasi dalam implementasinya berupaya menerapkan kegiatan 'penciptaan kembali' tersebut. Pengajar memberikan cukup ruang bagi pembelajar untuk menulis puisi berdasarkan unsur-unsur yang terdapat di dalam puisi lain yang pernah dibacanya. Tahap re-kreasi dapat diterapkan dalam bentuk:

(1) penciptaan kembali sebuah puisi berdasarkan tema puisi lain yang pernah dibaca, (2) penciptaan kembali puisi berdasarkan nada puisi lain yang pernah dibaca,

(3) penciptaan kembali sebuah puisi berdasarkan suasana puisi lain, dan

(4) penciptaan kembali puisi berdasarkan latar puisi lain.

Puisi yang telah ditulis oleh siswa kemudian dapat direvisi atau dilakukan penelaahan kembali tentang apa-apa yang kurang kemudian diberikan penilaian pada puisi tersebut. Cara melakukan setiap langkah tergantung dari teknik yang ingin 
digunakan oleh setiap guru. Strategi ini memungkinkan guru bekerja sama dengan siswa dalam bentuk kelompok maupun perseorangan.

\section{METODE PENELITIAN}

\section{Variabel Penelitian}

Variabel adalah gejala yang bervariasi dan dijadikan titik tolak atau titik perhatian dalam sebuah penelitian. Sesuai

\begin{tabular}{ccc}
\hline No & Kelas & Jumlah \\
\hline 1. & X1 & 25 \\
2. & X2 & 25 \\
3. & X3 & 27 \\
4. & X4 & 24 \\
\hline \multicolumn{2}{c}{ Jumlah } & 101 \\
\hline
\end{tabular}

dengan judul penelitian ini, variabel yang digunakan dalam penelitian ini adalah keefektifitan penerapan model stratta dalam pembelajaran menulis puisi siswa kelas XI SMA Negeri 1 Sungguminasa

\section{Desain Penelitian}

Desain atau model penelitian yang digunakan dalam penelitian ini adalah desain penelitian yang bersifat eksperimen jenis Posttest Eksperiment - Control Group Design.

Kelompok

Treatment

Postest

Eksperimen

$\mathrm{X}$

$\mathrm{T}$

Kontrol

$\mathrm{T}$

Keterangan: $\mathrm{X}=$ Treatment,$\quad \mathrm{T}=$ Tes Penelitian ini merupakan penelitian eksperimen yang melibatkan dua kelompok atau kelas, yaitu kelompok atau kelas eksperimen (kelompok atau kelas yang menggunakan model stratta dalam pembeljaran menulis puisi) dan kelompok atau kelas kontrol (kelompok atau kelas yang tidak menggunakan model stratta dalam pembelajaran menulis puisi).

\section{Definisi Operasional Variabel}

Definisi operasional variebel dimaksudkan untuk menghindari terjadinya salah penafsiran mengenai variabel dalam penelitian ini. Strategi stratta adalah suatu cara atau siasat untuk melahirkan ide dalam menulis karya sastra yang terdiri dari tiga tahapan. Yang pertama adalah tahap penjelajahan (siswa diminta membaca sebuah karya sastra), tahap kedua adalah tahap interpretasi (siswa diminta untuk mempresentasikan hasil penafsiran atau pemahaman tentang sebuah karya sastra), dan tahap ketiga adalah tahap re-kreasi (siswa diminta untuk mengkreasikan kembali apa yang telah dipahaminya tentang sebuah karya sastra).

\section{Populasi dan Sampel}

Populasi penelitian ini adalah semua siswa kelas XI SMA Negeri 1 Sungguminas yang terdiri datas empat kelas. Diasumsikan bahwa populasi dalam penelitian ini bersifat homogen karena penempatan siswa dalam suatu kelas tidak berdasarkan tingkat prestasi belajar siswa. Untuk lebih jelasnya dapt dilihat dari tabel 1 berikut ini:

Tabel 3.1 Keadaan Populasi

Penarikan sampel dalam penelitian ini menggunakan teknik purposive sampling, artinya penentuan sampel dilakukan secara sengaja dengan jumlah yang ditentukan sesaui dengan kebutuhan analisis. Sampel diambil dua kelas secara acak untuk ditetapkan sebagai kelas eksperimen dan kelas kontrol. Pembagian siswa ke dalam kelas eksperimen dan kelas kontrol secara acak dimungkinkan karena pendistribusian kemampuan siswa pada tiap-tiap kelas merata. Dengan demikian sampel dalam penelitian ini dikelompokkan dalam 2 kelompok, yaitu kelas X1 sebanyak 25 orang sebagai kelas eksperimen, dan kelas X3 sebanyak 25 orang sebagai kelas kontrol.

Data yang terkumpul dalam penelitian dianalisis dengan menggunakan teknik statistik inferensial. Adapun langkah-langkah menganalisis data sebagai berikut:

1. Membuat tabulasi skor siswa.

2. Menghitung persentase kemampuan tiap siswa dengan rumus berikut ini

$$
\begin{aligned}
& P=\frac{f g}{n} x 100 \begin{array}{l}
\text { Keterangan: } \\
\mathrm{P}=\text { kemampuan siswa }
\end{array} \\
& \mathrm{fg}=\text { jumlah jawaban benar } \\
& \mathrm{n}=\text { jumlam item (subjek } \\
& \text { penelitian) }
\end{aligned}
$$

3. Menghitung nilai rata-rata yang diperoleh siswa dengan menggunakan rumus berikut: 


$$
\bar{X}=\frac{\sum x}{N}
$$

Keterangan:

$$
\begin{array}{ll}
\bar{X} & =\text { nilai rata-rata } \\
\sum_{\mathrm{N}} x & =\text { jumlah jawaban keseluruhan } \\
& =\text { banyaknya subjek }
\end{array}
$$

4. Data yang diperoleh dianalisis dengan menggunakan teknik statistik inferensial ragam $\mathrm{t}$-Test sebagimana pendapat Arif Tiro (1999: 157) dengan rumus:

$$
t=\frac{M E-M K}{\sqrt{\frac{\sum b^{2}}{N(N-1)}}}
$$

Keterangan:

MK = Mean dari kelompok kontrol

$\mathrm{ME}=$ Mean dari kelompok

eksperimen

$\sum b^{2}=$ Jumlah deviasi dari mean

perbedaan

$\mathrm{N}=$ Pasangan subjek/sampel

$1=$ Bilangan tetap.

\section{HASIL PENELITIAN DAN PEMBAHASAN}

\section{A. Penyajian Hasil Analisis Data}

Data yang diperoleh dari hasil penerapan strategi stratta dalam meningkatkan kemampuan menulis puisi siswa kelas XI SMA Negeri 1 Sungguminasa. selanjutnya dianalisis sesuai dengan teknik analisis data yang telah diuraikan pada bab III, yaitu menggunakan analisis statistik deskriptif jenis uji t. Penyajian hasil analisis terdiri atas dua, yakni penyajian data nilai siswa kelas eksperimen dan nilai kelas kontrol. Adapun penyajiannya, dapat dilihat sebagai berikut ini.

\section{Analisis Nilai Kelas Eksperimen (ME)}

Berdasarkan hasil analisis data dengan 25 orang siswa yang dianalisis diperoleh gambaran, yaitu tidak ada siswa yang mampu memperoleh nilai 100 sebagai nilai maksimal. Nilai tertinggi yang dicapai oleh siswa adalah 90 yang dicapai oleh 4 orang $(16 \%)$ dan nilai terendah yang diperoleh oleh siswa adalah 76,6 yang dicapai oleh 3 siswa (12\%). Selanjutnya, sampel yang mendapat nilai 86,7 berjumlah 2 orang (8\%); sampel yang mendapat nilai 83,3 berjumlah 8 orang (32\%); sampel yang mendapat nilai 80 berjumlah 7 orang (28\%); sampel yang mendapat nilai 76,7 berjumlah 1 orang (4\%); Gambaran yang lebih jelas dan tersusun rapi dari nilai tertinggi sampai dengan nilai terendah yang diperoleh siswa beserta frekuensinya dapat dilihat pada Tabel 3 berikut ini.

Tabel 4.1 Distribusi Frekuensi dan Persentase Nilai Siswa Kelas Eksperimen (ME)

\begin{tabular}{llll}
\hline No. & Nilai & Frekuensi & $\begin{array}{l}\text { Persentase } \\
(\%)\end{array}$ \\
\hline 1. & 90 & 4 & 16 \\
2. & 86,7 & 2 & 8 \\
3. & 83,3 & 8 & 32 \\
4. & 80 & 7 & 28 \\
5. & 76,7 & 1 & 4 \\
6. & 76,6 & 3 & 12 \\
\hline \multicolumn{2}{l}{ Jumlah } & 25 & 100 \\
\hline
\end{tabular}

Berdasarkan perolehan nilai dan persentase di atas, dapat diketahui jumlah nilai kemampuan Menulis puisi dengan menggunakan strategi stratta siswa kelas XI SMA Negeri 1 Sungguminasa, seperti tampak pada tabel 2

\begin{tabular}{|c|c|c|c|}
\hline No. & $\begin{array}{l}\text { Nilai } \\
\text { (ME) }\end{array}$ & $\begin{array}{l}\text { Frekuensi } \\
\text { (N) }\end{array}$ & $\begin{array}{l}\text { Jumlah } \\
\sum M E\end{array}$ \\
\hline 1. & 90 & 4 & 360 \\
\hline 2. & 86,7 & 2 & 173.4 \\
\hline 3. & 83,3 & 8 & 666.4 \\
\hline 4. & 80 & 7 & 560 \\
\hline 5. & 76,7 & 1 & 76.7 \\
\hline 6. & 76,6 & 3 & 229.8 \\
\hline \multicolumn{2}{|c|}{ Jumlah } & 25 & 2066.3 \\
\hline
\end{tabular}
berikut ini.

Tabel 4.2 Jumlah Nilai Siswa Kelas Eksperimen (ME)

Berdasarkan tabel 4.2 di atas, diketahui bahwa nilai rata-rata kemampuan menulis puisi dengan menggunakan strategi stratta siswa kelas XI SMA Negeri 1 Sungguminasa adalah yang diperoleh dari hasil bagi jumlah seluruh nilai ( $\sum M E$ ) dengan jumlah siswa sampel (N) atau ( $\sum M E / \mathrm{N}=2066.3 / 25=82.6$ ). 
Tabel 4.3 Klasifikasi Nilai Kemampuan Menulis puisi dengan Menggunakan Strategi stratta Siswa Kelas XI SMA Negeri 1 Sungguminasa Kelas Eksperimen

\begin{tabular}{lllll}
\hline No. & $\begin{array}{l}\text { Kemampuan } \\
(\mathbf{P})\end{array}$ & $\begin{array}{l}\text { Frekuensi } \\
(\mathbf{f})\end{array}$ & $\begin{array}{l}\text { Persentase } \\
(\boldsymbol{\%})\end{array}$ & $\begin{array}{l}\text { Tingkat } \\
\text { Penguasaan }\end{array}$ \\
\hline 1. & $91-100$ & 0 & 0 & Sangat \\
2. & $76-90$ & 25 & 100 & tinggi \\
3. & $61-75$ & 0 & 0 & Tinggi \\
4. & $51-60$ & 0 & 0 & Sedang \\
5. & 50 ke bawah & 0 & 0 & $\begin{array}{l}\text { Rendah } \\
\text { Sangat } \\
\text { rendah }\end{array}$ \\
\hline & & & & \\
\hline
\end{tabular}

(Adaptasi dari Depdiknas, 2006)

Berdasarkan kategori kemampuan tersebut, dapat dinyatakan bahwa tidak ada siswa yang memperoleh nilai pada kategori kemampuan sangat tinggi (0\%). Selanjutnya, sampel yang memperoleh nilai pada kategori kemampuan tinggi sebanyak 25 orang $(100 \%)$; tidak ada sampel yang memperoleh nilai pada kategori kemampuan sedang, rendah, dan sangat rendah. Hal ini menunjukkan bahwa tingkat kemampuan menulis puisi dengan menggunakan strategi stratta siswa kelas XI SMA Negeri 1 Sungguminasa dikategorikan tinggi.

Nilai siswa tersebut dapat dikonversikan ke dalam tabel klasifikasi tingkat kemampuan menulis puisi dengan menggunakan strategi stratta siswa kelas XI SMA Negeri 1 Sungguminasa. Untuk mengetahui tingkat kemampuan menulis puisi dengan menggunakan strategi stratta siswa kelas XI SMA Negeri 1 Sungguminasa, dapat dilihat tabel 4.4 berikut ini:

Tabel 4.4 Klasifikasi Tingkat Kemampuan Menulis puisi dengan Menggunakan Strategi stratta Siswa Kelas XI SMA Negeri 1 Sungguminasa Kelas Eksperimen (ME)

\begin{tabular}{lll}
\hline Nilai & Frekuensi & Persentase (\%) \\
\hline 70 ke atas & 25 & 100 \\
di bawah 70 & 0 & 0 \\
\hline Jumlah & 25 & 100 \\
\hline
\end{tabular}

Berdasarkan tabel 4.4 di atas dapat dikelahui, bahwa sampel yang memperoleh nilai 70 ke atas berjumlah 25 siswa (100\%) dan tidak ada siswa sampel yang memperoleh nilai di bawah 70 $(0 \%)$. Dengan demikian, dapat dikatakan bahwa kemampuan menulis puisi dengan menggunakan strategi stratta siswa kelas XI SMA Negeri 1 Sungguminasa kelas eksperimen memadai.Hal ini dibuktikan dari nilai yang diperoleh siswa sampel yang memperoleh nilai 70 ke atas mencapai kriteria tingkat kemampuan siswa sampel yaitu $85 \%$.

\section{Analisis Nilai Kelas Kontrol (MK)}

Berdasarkan hasil analisis data sebanyak 25 orang siswa yang dianalisis diperoleh gambaran, yaitu tidak ada siswa yang mampu memperoleh nilai 100 sebagai nilai maksimal. Nilai tertinggi yang dicapai oleh siswa adalah 53.3 yang dicapai oleh 3 orang (12\%) dan nilai terendah yang diperoleh oleh siswa adalah 17.5 yang dicapai oleh 1 siswa (4\%).

Selanjutnya, sampel yang mendapat nilai 50 berjumlah 3 orang (12\%); sampel yang mendapat nilai 47,6 berjumlah 3 orang (12\%); sampel yang mendapat nilai 43,3 berjumlah 3 orang (12\%); sampel yang mendapat nilai 60 berjumlah 6 orang (24\%); sampel yang mendapat nilai 37,6 berjumlah 1 orang (4\%); sampel yang mendapat nilai 36,6 berjumlah 2 orang (8\%); sampel yang mendapat nilai 33.3 berjumlah 1 orang (4\%); sampel yang mendapat nilai 30 berjumlah 1 orang (4\%); sampel yang mendapat nilai 23,3 berjumlah 1 orang (4\%).

Gambaran yang lebih jelas dan tersusun rapi dari nilai tertinggi sampai dengan nilai terendah yang diperoleh siswa beserta frekuensinya dapat dilihat pada Tabel 5 berikut ini.

Tabel 4.5 Distribusi Frekuensi dan Persentase Skor Siswa Kelas Kontrol (MK) 


\begin{tabular}{llll}
\hline No. & Nilai & Frekuensi & $\begin{array}{l}\text { Persentase } \\
(\boldsymbol{\%})\end{array}$ \\
\hline 1. & 53,3 & 3 & 12 \\
2. & 50 & 3 & 12 \\
3. & 47,6 & 3 & 12 \\
4. & 43,3 & 3 & 12 \\
5. & 40 & 6 & 24 \\
6. & 37,6 & 1 & 4 \\
7. & 36,6 & 2 & 8 \\
8. & 33,3 & 1 & 4 \\
9. & 30 & 1 & 4 \\
10. & 23,3 & 1 & 4 \\
\multicolumn{2}{l}{ Jumlah } & & \\
\hline
\end{tabular}

Berdasarkan perolehan nilai dan persentase di atas, dapat diketahui jumlah nilai kemampuan menulis puisi tanpa menggunakan strategi stratta siswa kelas XI SMA Negeri 1 Sungguminasa, seperti tampak pada tabel 8 berikut ini.

Tabel 4.6. Jumlah Nilai Siswa Kelas Kontrol ( $\left.\sum M K\right)$.

\begin{tabular}{|c|c|c|c|}
\hline No. & $\begin{array}{l}\text { Nilai } \\
\text { (MK) }\end{array}$ & $\begin{array}{l}\text { Frekuensi } \\
\text { (N) }\end{array}$ & $\begin{array}{l}\text { Jumlah } \\
\text { Nilai } \\
\sum M K\end{array}$ \\
\hline 1. & 53,3 & 3 & 159.9 \\
\hline 2. & 50 & 3 & 150 \\
\hline 3. & 47,6 & 3 & 142.8 \\
\hline 4. & 43,3 & 3 & 129.9 \\
\hline 5. & 40 & 6 & 240 \\
\hline 6. & 37,6 & 1 & 37.6 \\
\hline 7. & 36,6 & 2 & 73.2 \\
\hline 8. & 33,3 & 1 & 33.3 \\
\hline 9. & 30 & 1 & 30 \\
\hline 10. & 23,3 & 1 & 23.3 \\
\hline 11. & 17,5 & 1 & 17.5 \\
\hline \multicolumn{2}{|c|}{ Jumlah } & 25 & 1037.5 \\
\hline
\end{tabular}

Berdasarkan tabel 4.6 di atas, diketahui bahwa nilai rata-rata kemampuan menulis puisi tanpa menggunakan strategi stratta siswa kelas XI SMA Negeri 1 Sungguminasa adalah 41,5 yang diperoleh dan hasil bagi jumlah seluruh nilai ( $\left.\sum M K\right)$ dengan jumlah siswa sampel $(\mathrm{N})$ atau ( $\left.\sum M K / \mathrm{N}=1037,5 / 25=41,5\right)$.

Tabel 4.7 Klasifikasi Nilai Kemampuan Menulis puisi dengan Menggunakan Strategi stratta Siswa Kelas XI SMA Negeri 1 Sungguminasa Kelas Eksperimen

\begin{tabular}{lllll}
\hline No. & Kemampuan (P) & Frekuensi (f) & Persentase (\%) & $\begin{array}{l}\text { Tingkat } \\
\text { Penguasaan }\end{array}$ \\
\hline 1. & $91-100$ & 0 & 0 & Sangat tinggi \\
2. & $76-90$ & 0 & 0 & Tinggi \\
3. & $61-75$ & 0 & 0 & Sedang \\
4. & $51-60$ & 3 & 12 & Rendah \\
5. & 50 ke bawah & 22 & 88 & Sangat rendah \\
\hline & Jumlah & 25 & 100 & \\
\hline
\end{tabular}

(Adaptasi dari Depdiknas, 2006)

Berdasarkan kategori kemampuan tersebut, dapat dinyatakan bahwa tidak ada siswa yang memperoleh nilai pada kategori kemampuan sangat tinggi, tinggi, dan sedang (0\%). Selanjutnya, sampel yang memperoleh nilai pada kategori kemampuan rendah sebanyak 3 orang (12\%); sampel yang memperoleh nilai pada kategori kemampuan sangat rendah sebanyak 22 orang $(88 \%)$. Hal ini menunjukkan bahwa tingkat kemampuan menulis puisi tanpa menggunakan strategi stratta siswa kelas XI SMA Negeri 1 Sungguminasa dikategorikan sangat rendah.
Nilai siswa tersebut dapat dikonversikan ke dalam tabel klasifikasi tingkat kemampuan menulis puisi tanpa menggunakan strategi stratta siswa kelas XI SMA Negeri 1 Sungguminasa. Untuk mengetahui tingkat kemampuan menulis puisi tanpa menggunakan strategi stratta siswa kelas XI SMA Negeri 1 Sungguminasa, dapat dilihat tabel 4.8 berikut ini:

Tabel 4.8. Klasifikasi Tingkat Kemampuan Menulis puisi Tanpa Menggunakan Strategi stratta Siswa Kelas XI SMA Negeri 1 Sungguminasa Kelas Kontrol (MK). 


\begin{tabular}{lll}
\hline Nilai & Frekuensi & Persentase (\%) \\
\hline 70 ke atas & 0 & 0 \\
di bawah 70 & 25 & 100 \\
\hline Jumlah & 25 & 100 \\
\hline \multicolumn{4}{c}{ Berdasarkan tabel } & 4.8 di atas, dapat
\end{tabular}

dikelahui bahwa tidak ada sampel yang memperoleh nilai 70 ke atas $(0 \%)$, sedangkan siswa sampel yang memperoleh nilai di bawah 70 berjumlah 25 siswa (100\%). Dengan demikian, dapat dikatakan bahwa kemampuan menulis puisi tanpa menggunakan strategi stratta siswa kelas XI Negeri 1 Sungguminasa kelas kontrol (MK) belum memadai. Hal ini dibuktikan dari nilai yang diperoleh sisa sampel yang memperoleh nilai $70 \mathrm{ke}$ atas tidak mencapai kriteria tingkat kemampuan siswa sampel yaitu $85 \%$. Selain itu, perolehan nilai siswa tersebut tidak mencapai ketuntasan yang ditetapkan oleh kurikulum sekolah, yakni $85 \%$ siswa yang harus mendapat nilai $70 \mathrm{ke}$ atas.

\section{Analisis Keefektifan Penerapan Strategi stratta dalam Meningkatkan Kemampuan Menulis puisi Siswa Kelas XI SMA Negeri 1} Sungguminasa

Pada bagian ini dipaparkan keefektifan strategi stratta dalam meningkatkan kemampuan menulis puisi siswa kelas XI SMA Negeri 1 Sungguminasa. Keefektifan strategi stratta dalam meningkatkan kemampuan menulis puisi siswa kelas XI SMA Negeri 1 Sungguminasa tersebut diukur berdasarkan perolehan nilai kelas eksperimen dan kelas kontrol. Selanjutnya, berdasarkan perolehan nilai kelas eksperimen dan kelas kontrol dilakukan perhitungan dalam bentuk tabel kerja berikut ini.

Tabel 4.9 Tabel Kerja Keefektifan Strategi stratta dalam Meningkatkan Kemampuan Menulis Puisi Siswa Kelas XI SMA Negeri 1 Sungguminasa.

\begin{tabular}{|c|c|c|c|c|c|c|}
\hline \multicolumn{2}{|c|}{ Pasangan Subjek } & \multicolumn{2}{|l|}{ Nilai } & \multirow{2}{*}{$\begin{array}{l}\text { B } \\
\text { KE-KK }\end{array}$} & \multirow{2}{*}{$\begin{array}{l}b \\
-(B+M B)\end{array}$} & \multirow[t]{2}{*}{$\mathbf{b}^{2}$} \\
\hline KE & KK & KE & KK & & & \\
\hline 1 & 1 & 80 & 53,3 & 26.7 & 67.85 & 4603.623 \\
\hline 2 & 2 & 80 & 47,6 & 32.4 & 73.55 & 5409.603 \\
\hline 3 & 3 & 76,7 & 30 & 46.7 & 87.85 & 7717.623 \\
\hline 4 & 4 & 83,3 & 36,6 & 46.7 & 87.85 & 7717.623 \\
\hline 5 & 5 & 86,7 & 36,6 & 50.1 & 91.25 & 8326.563 \\
\hline 6 & 6 & 83,3 & 50 & 33.3 & 74.45 & 5542.803 \\
\hline 7 & 7 & 83,3 & 43,3 & 40 & 81.15 & 6585.323 \\
\hline 8 & 8 & 86,7 & 37,6 & 49.1 & 90.25 & 8145.063 \\
\hline 9 & 9 & 90 & 50 & 40 & 81.15 & 6585.323 \\
\hline 10 & 10 & 76,6 & 47,6 & 29 & 70.15 & 4921.023 \\
\hline 11 & 11 & 76,6 & 40 & 36.6 & 77.75 & 6045.063 \\
\hline 12 & 12 & 80 & 53,3 & 26.7 & 67.85 & 4603.623 \\
\hline 13 & 13 & 83,3 & 40 & 43.3 & 84.45 & 7131.803 \\
\hline 14 & 14 & 83,3 & 40 & 43.3 & 84.45 & 7131.803 \\
\hline 15 & 15 & 80 & 53,3 & 26.7 & 67.85 & 4603.623 \\
\hline 1 & 2 & 3 & 4 & 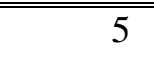 & 6 & 7 \\
\hline 16 & 16 & 83,3 & 33,3 & 50 & 91.15 & 8308.323 \\
\hline 17 & 17 & 80 & 50 & 30 & 71.15 & 5062.323 \\
\hline
\end{tabular}




\begin{tabular}{|c|c|c|c|c|c|c|}
\hline 18 & 18 & 83,3 & 17,5 & 65.8 & 106.95 & 11438.3 \\
\hline 19 & 19 & 76,6 & 40 & 36.6 & 77.75 & 6045.063 \\
\hline 20 & 20 & 90 & 40 & 50 & 91.15 & 8308.323 \\
\hline 21 & 21 & 83,3 & 43,3 & 40 & 81.15 & 6585.323 \\
\hline 22 & 22 & 90 & 40 & 50 & 91.15 & 8308.323 \\
\hline 23 & 23 & 80 & 23,3 & 56.7 & 97.85 & 9574.623 \\
\hline 24 & 24 & 90 & 47,6 & 42.4 & 83.55 & 6980.603 \\
\hline 25. & 25 & 80 & 43,3 & 36.7 & 77.85 & 6060.623 \\
\hline \multirow[t]{2}{*}{ Total } & & $\sum \mathrm{KE}=2066.3$ & $\sum K K=1037.5$ & $\sum \mathrm{B}=1028,8$ & - & \\
\hline & & $\mathrm{ME}=82,6$ & $\mathrm{MK}=41,5$ & $\mathrm{MB}=41,15$ & & \\
\hline
\end{tabular}

Berdasarkan tabel kerja tersebut diperoleh nilai sebagai berikut:

$$
\begin{array}{ll}
\mathrm{MK} & =41,5 \\
\mathrm{ME} & =82,6 \\
\sum \mathrm{b}^{2} & =171742.3 \\
\mathrm{~N} & =25
\end{array}
$$

Angka-angka di atas selanjutnya dimasukkan ke dalam rumus untuk mengetahui koefisien $t$ dari perhitungan t-test.

Berdasarkan hasil analisis data yang diuraikan di atas, terlihat bahwa nilai keefektifan strategi stratta dalam meningkatkan kemampuan menulis Puisi siswa kelas XI SMA Negeri 1 Sungguminasa sebesar 2,43. Berdasarkan nilai $t$ hitung tersebut dapat dibandingkan dengan nilai $\mathrm{t}$ tabel $\mathrm{db}=\mathrm{N}-1=25-1=24$. Jadi, db 25-1 = 24 dan $\mathrm{t}=0,5$ (tabel terlampir). Sementara, $\mathrm{t}$ hitung $=2,43$ dan $\mathrm{t}$ tabel $=2,064$ (signifikan 5\%). Dengan demikian, $\mathrm{t}$ hitung $>\mathrm{t}$ tabel.

Hipotesis yang diuji dengan statistik uji $t$, yaitu strategi stratta efektif diterapkan dalam meningkatkan kemampuan menulis puisi siswa kelas XI SMA Negeri 1 Sungguminasa Dalam penelitian ini, terungkap bahwa nilai hasil pembelajaran menulis puisi siswa yang menggunakan strategi stratta memiliki hasil belajar yang lebih tinggi dibandingkan dengan nilai siswa yang tidak menerapkan strategi stratta

Setelah diadakan perhitungan berdasarkan hasil statistik inferensial jenis uji $t$ diperoleh nilai $\mathrm{t}$ hitung: 2,43. Kriteria pengujiannya adalah $\mathrm{H} 0$ diteri ma jika $\mathrm{t}$ hitung $<\mathrm{t}$ Tabel dan $\mathrm{H} 0$ ditolak jika $\mathrm{t}$ hitung $>\mathrm{t}$ tabel. Nilai $\mathrm{t}$ tabel $=\mathrm{db}=1=25-1$ $=24$ (Angka 24 inilah yang dilibat dalam tabel).
Pada taraf signifikan 5\% diperoleh $=2,064$, ternyata $\mathrm{t}$ hitung $>\mathrm{t}$ tabel dan hipotesis kerja penelitian ini diterima. Dengan demikian, strategi stratta efektif diterapkan dalam meningkatkan kemampuan menulis puisi siswa kelas XI SMA Negeri 1 Sungguminasa, maka $\mathrm{H} 1$ diterima dan $\mathrm{HO}$ ditolak.

\section{KESIMPULAN}

Berdasarkan hasil analisis data dan pembahasan dapat disimpulkan tentang keefektifan penerapan strategi stratta dalam meningkatkan kemampuan menulis puisi siswa kelas XI SMA Negeri 1 Sungguminasa Hasil penelitian ini menunjukkan bahwa:

Pertama, kemampuan menulis puisi siswa XI SMA Negeri 1 Sungguminasa setelah diterapkan strategi stratta, menunjukkan hasil yang memadai dalam meningkatkan kemampuan menulis puisi.

Kedua, strategi stratta efektif diterapkan dalam meningkatkan kemampuan menulis puisi siswa kelas XI SMA Negeri 1 Sungguminasa. Hal ini dinyatakan berdasarkan hasil perhitungan tes signifikansi untuk desain 2 yang menunjukkan bahwa nilai terhitung sebanyak $2,43>$ nilai t tabel 2,064. Hal ini menunjukkan bahwa hipotesis penelitian yang diajukan diterima.

\section{DAFTAR PUSTAKA}

Achadiah, S. Arsjad, M. G. \& Ridwan. 1994. Pembinaan Kemampuan Menulis Bahasa Indonesia. Jakarta: Erlangga. 
Aminuddin. 2009. Pengantar Apresiasi Karya Sastra. Malang: Sinar Baru Algasindo.

Arif Tiro, Muhammad. 1999. Dasar-Dasar Statistika. Makassar: Universitas Negeri Makassar.

Departemen Pendidikan Nasional. 2007. Kamus Besar Bahasa Indonesia. Jakarta: Balai Pustaka.

Firman. 2003. "Keterampilan Siswa Kelas II SLTPN I Sajoanging, Kabupaten Wajo Menulis Pengalaman Pribadi dalam Bentuk Puisi”. Skripsi. Makassar: Fakultas Bahasa dan Seni Universitas Negeri Makassar.

Halimah. 2006. "Penerapan Strategi Pembelajaran Kooperatif Tipe STAD pada Siswa Kelas X SMA Negeri 1 Campalagian Kabupaten Polewali Mandar." Tesis. Tidak Diterbitkan. Makassar: PPs UNM.

Hamid, Mukhlis A. 2005. Antara Harapan dan Kenyataan. Makalah disampaikan pada "Dialog Sastra 1996", Jangka Bireuen, 21 Desember 1996.

Hartoko, A. 1989. Penuntun Tulis Menulis. Banjarmasin: Aulia.

Suhartini. 2005. "Kemampuan Menulis Puisi Siswa Kelas III Bahasa SMA Negeri 1 Bajeng”. Skripsi. Makassar: Fakultas Bahasa dan Seni Universitas Negeri Makassar.

Sulastriningsih, dan Mahmudah. 2007. Pengajaran Prosa Fiksi dan Drama. Makassar: Badan Penerbit UNM.

Slavin, Robert E,. 1995. Cooperative Learning: Theory Research and Practice. London: Allymand Bacon Publisher.

Sutjarso. 2006. Pengajaran Puisi Indonesia. Makassar.

Syafi'ie, Imam. 1988. Retorika dalam Menulis. Jakarta: Depdikbud.

Lukman, Andi. 2008. "Kemampuan Siswa Kelas IX SMP Negeri 2 Binamu Kabupaten Jeneponto Menulis Simulasi Dongeng”. Skripsi. Makassar: FBS UNM.

Mirriam, Caryn. 2006. Daripada Bete Nulis Aja. Bandung: Kaifa.h

Nurgiyantoro, Burhan. 1995. Penilaian dan Pengajaran Bahasa dan Sastra. Yogyakarta: BPFE.

Pradopo, Rachmat Djoko. 2002. Pengkajian Puisi. Yogyakarta: Gadjah Mada University Press.
Rahmanto. 1988. Metode Pengajaran Sastra. Yogyakarta: Kanisius

Roekhan. 1991. Menulis Kreatif Dasar-Dasar dan Petunjuk Penerapannya. Malang: Yayasan Asih Asah Asuh Malang.

Waluyo, Herman J. 1995. Teori dan Apresiasi Puisi. Jakarta: Erlangga. 